\title{
STUDY OF SHALLOW GROUNDWATER CHARACTERISTICS IN SANGIRAN DOME, KALIJAMBE DISTRICT
}

\author{
Cikal Lembayu ${ }^{1}$, Chatarina Muryani ${ }^{2}$, Setya Nugraha ${ }^{3}$ \\ ${ }^{123}$ Geography Education, Faculty of Teacher Training and Education, \\ Universitas Sebelas Maret Surakarta \\ E-mail: cikallembayu96@gmail.com
}

\begin{abstract}
The purpose of this study are knowing the shallow groundwater flow patterns and characteristics in the Sangiran Dome. This research uses descriptive qualitative method, carried out with survey methods that are analyzed with spatial approach. Unit analysis of this studied is the landform unit the result of a overlay between the Geological's Map, Genesis's Process, and Slope's Map, the result is 15 landform units. Data analysis techniques is to determine the pattern of shallow groundwater flow using the three point problem method. Data analysis is to determine the characteristics of groundwater by using the parameters of power oh Hydrogen $(\mathrm{pH})$, temperature, and Electrical Conductivity $(D H L)$. The results of this study are the shallow groundwater flow patterns in the Sangiran Dome are concentrated in the Kalibeng Formation, the diffuse flow patterns are in the Pucangan Formation and irregular flow patterns are found in Kabuh Formation and Noropuro. The characteristics of shallow groundwater in the Sangiran Dome, based on $\mathrm{pH}$. Neutral classification are found in the Notopuro Formation, the lower Pucangan Formation; base pH classification found in Kabuh Formation, upper Pucangan Formation, and Kalibeng Formation; acidic pH classification is found in the Notopuro Formation. The low DHL classification is found in Notopuro Formation, Kabuh Formation, and Pucangan Formation while the moderate DHL classification is in the Kalibeng Formation.
\end{abstract}

Keywords: Shallow Groundwater, Landform Unit, Sangiran Dome.

\section{A. INTRODUCTION}

Water is a very important requirement for human life. Water is used for various needs including drinking, bathing, washing and cooking. Water used for daily needs in every place and level is not the same, meaning that the higher the standard of living needs of humans, the more the amount of water needed is also increasing. Clean water is water that does not cause negative impacts when used for a particular purpose. Water is said to be clean if it meets the requirements in accordance with the intended use of clean water for drinking water needs, it must meet the physical, chemical, microbiological, and other requirements. In accordance with the Standards of the Ministry of Health of the Republic of Indonesia (Agustina, 2013: 2).

According to Hadian et al. (2006: 121) in Zefittni (2012: 106), one of the potential water resources and gets a lot of attention in relation to meeting the needs 
is groundwater. The role of groundwater is increasingly important because groundwater is the main source of water to meet the basic needs of the livelihood of many people (common goods), such as drinking water, households, industry, irrigation, urban areas and others, and has become an economic commodity even in some places. become a strategic commodity. It is estimated that $70 \%$ of the population's clean water needs and $90 \%$ of industrial water needs come from groundwater. Indirectly, the need for clean water is increasing.

Sangiran Dome is located in Kalijambe District, Sragen Regency. Communities around the Sangiran Dome are very dependent on clean water. The need for clean water is increasing, followed by population growth. Based on the results of direct interviews with several residents in the vicinity of Sangiran Dome, before there was clean water from the Regional Water Supply Company (PDAM), residents still used shallow groundwater wells to get clean water. Shallow groundwater wells used by local residents for the needs of bathing, washing, toilet (MCK), as well as drinking and cooking needs.

Notosiswoyo (2002) in Zeffitni (2012: 104), states that groundwater is a renewable resource, but the time to replenish it is very relative. The study of spatial distribution of groundwater potential is inseparable from the environmental spatial analysis approach. Todd (1980: 43) in Zeffitni (2012: 106) argues that the groundwater basin is a hydrogeological unit consisting of one or several interconnected aquifer parts forming a system and can change due to environmental changes.

People's around the Sangiran Dome, often fail when making shallow groundwater wells. One of the failures that occurred was because the community did not know the condition of the soil, rocks, and groundwater zones. Hydrogeology is the relationship between the existence, spread, and flow of groundwater in the perspective of geology (Todd, 1980 in Devy, 2015: 1). Naturally, groundwater contains chemical elements which are the result of the hydrological process from the formation of water vapor in the atmosphere until water flows on the surface and below the surface. Todd (1980: 42), variations in rock minerals will form elements of chemical compounds that affect groundwater quality. The variation of the rock formation layer also affects the difference in the ability to store water and groundwater quality. Groundwater quality changes along with groundwater travel, 
especially in its chemical composition. This change is influenced by the media where groundwater flows (rock layers) which have a certain rock mineral composition. Changes in the composition of groundwater elements occur because of the reaction of groundwater elements with the chemical elements of rock minerals which will affect the characteristics of groundwater. The characteristics of groundwater can be known through the measurement of 3 parameters, namely, $\mathrm{pH}$, temperature, and Electrical Resistance Power (DHL).

\section{B. MATERIALS AND METHODS}

This research uses a descriptivequalitative approach which is conducted by survey method because it is measured directly in the field. Descriptivequalitative method is research that leads to existing problems and is expressed based on facts or facts that are appropriate, and sometimes provides interpretation or analysis (Tika, 2005: 6).

This study uses spatial analysis which is used to determine the direction of shallow groundwater flow based on shallow groundwater level and shallow groundwater characteristics in each landform unit based on parameters of temperature, degree of acidity $(\mathrm{pH})$, and Electrical Power (DHL).

Data collection techniques were carried out by means of observation to obtain groundwater level, $\mathrm{pH}$, temperature, and DHL data. Interviews were conducted to obtain data into shallow groundwater wells, shallow groundwater utilization to meet daily needs, and shallow groundwater conditions during the rainy and dry seasons.

\section{RESULTS AND DISCUSSION}

1. Shallow Groundwater Flow Pattern at Sangiran Dome

Based on the results of overlapping Geological Maps, Genesis Processes, and Slope Maps, there are 15 landform units. However, from the 15 landform units there are only 7 landforms found in shallow groundwater wells. This is because some people have permanently closed shallow groundwater wells and switched to using the Regional Water Company (PDAM). The distribution of shallow groundwater wells will be shown on Figure 1. 


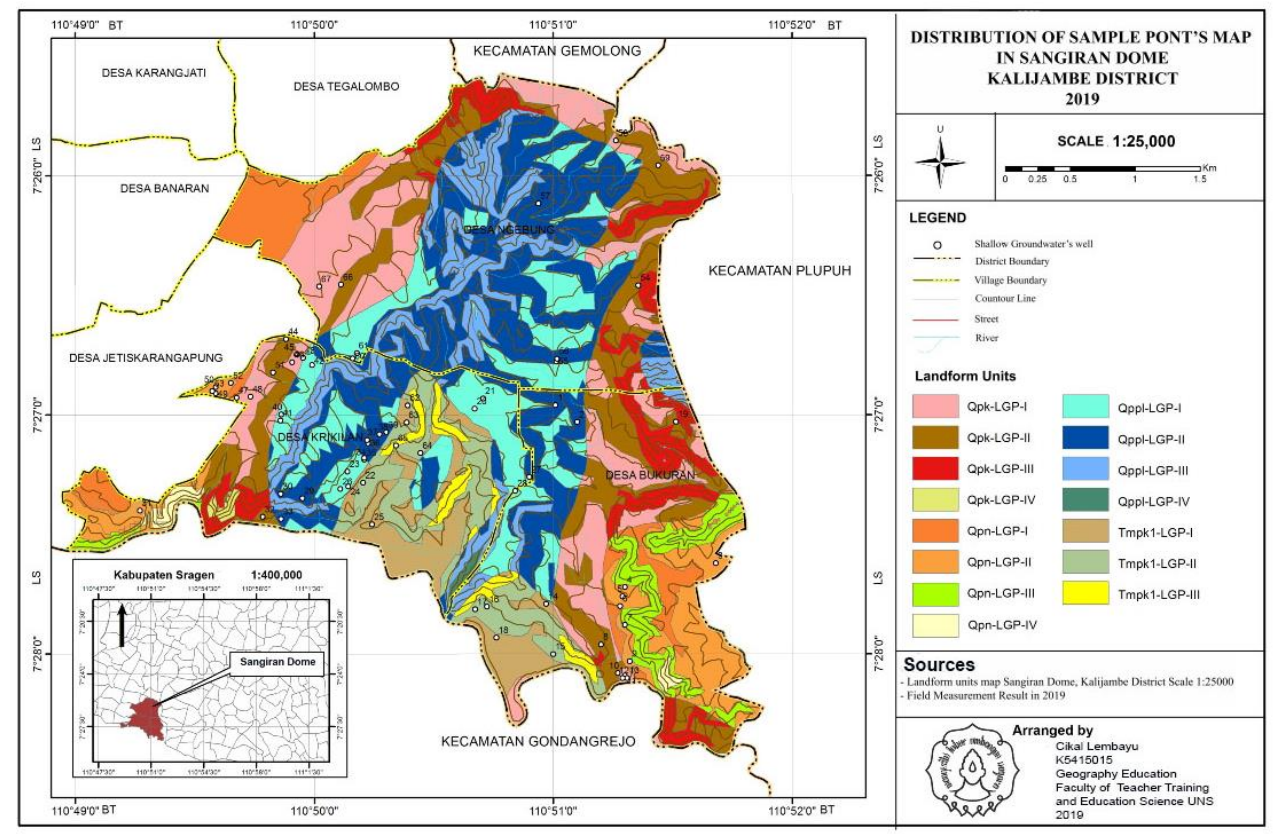

Figure 1. Distribution of Shallow Groundwater Well in the Sangiran Dome

After conducting a field survey, not every landform unit has shallow groundwater wells because it has been permanently closed, there are only 67 shallow groundwater wells spread over 7 landform units. The distribution of shallow groundwater wells contained in each unit of landform is presented in table 1 below.

\begin{tabular}{cccc}
\hline Number. & Landform Units & Area (ha) & Number of shallow groundwater wells \\
1. & Qpk-LGP-I & 190,41 & 10 \\
2. & Qpk-LGP-II & 174,32 & 9 \\
3. & Qpk-LGP-III & 89,20 & None \\
4. & Qpk-LGP-IV & 3,40 & Unmeasurable \\
5. & Qpn-LGP-I & 73,69 & None \\
6. & Qpn-LGP-II & 79,53 & 11 \\
7. & Qpn-LGP-III & 46,43 & None \\
8. & Qpn-LGP-IV & 8,50 & None \\
9. & Qppl-LGP-I & 168,84 & 11 \\
10. & Qppl-LGP-II & 272,29 & 15 \\
11. & Qppl-LGP-III & 168,84 & Unmeasurable \\
12. & Qppl-LGP-IV & 2,29 & None \\
13. & Tmpk1-LGP-I & 71,70 & 5 \\
14. & Tmpk1-LGP-II & 73,72 & 6 \\
15. & Tmpk1-LGP-III & 22,28 & None \\
\hline
\end{tabular}

Source: Field Survey Results in 2019

Determination of shallow groundwater flow patterns is done by calculating shallow groundwater level. Table 2 will show the results of the calculation of shallow groundwater level. Groundwater will flow from high groundwater level to low groundwater level. Based on the flow pattern, the Sangiran Dome has the following flow patterns. Pattern of 
shallow groundwater shown in figure

2.

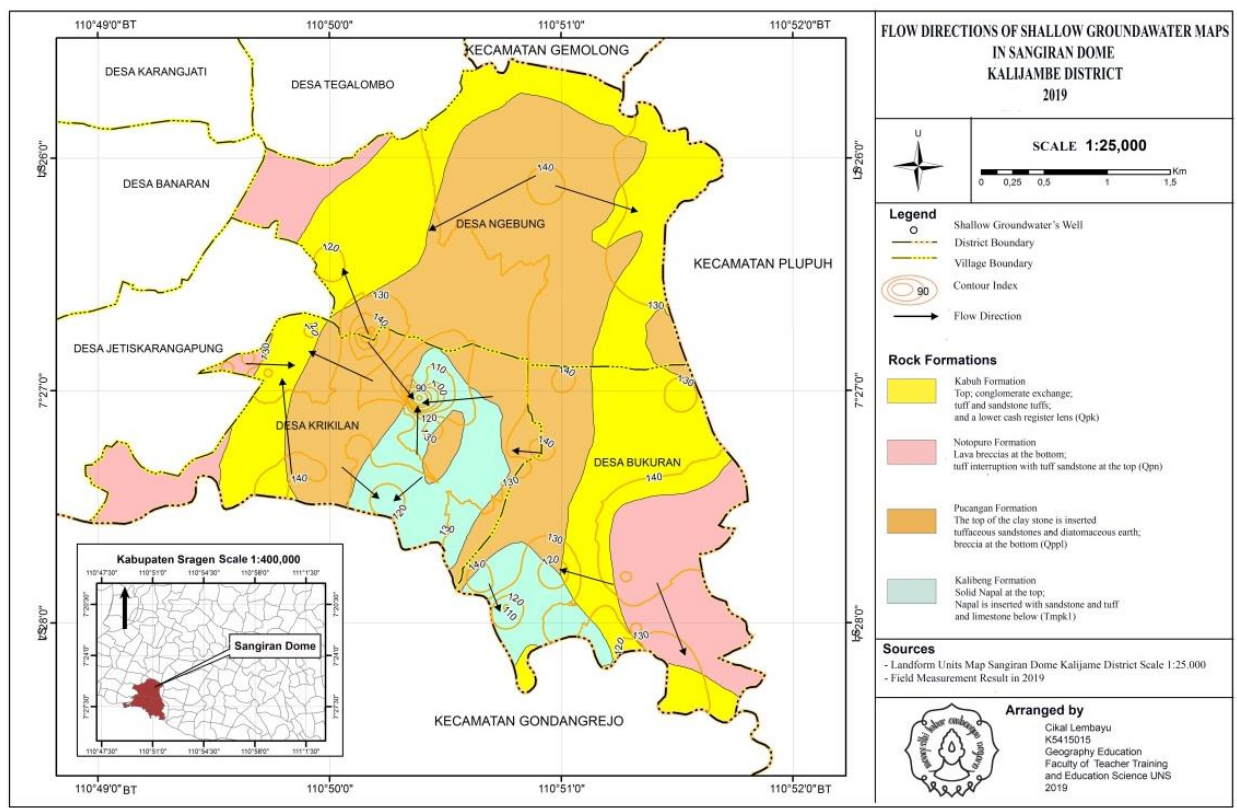

Figure 2. Shallow Groundwater Flow Patterns at Sangiran Dome in 2019

Based on the map above, it can be seen the pattern of groundwater flow in the Sangiran Dome, namely:

a) Centering Flow Pattern

This groundwater flow pattern is in the Kalibeng Formation land unit with a slope of $0 \%-3 \%$ and the Kalibeng Formation with a slope of $3 \%$ $8 \%$. Both of these landform units are located in Kalibeng. The direction of groundwater flow is centered according to the direction and slope of the rock layers in the Sangiran Dome. Groundwater flows from West to East. This groundwater flow pattern is found in Krikilan Village.

b) Spread Flow Pattern

This groundwater flow pattern is found in the Pucangan Formation landform unit with a slope slope of $0 \%-3 \%$ and the Pucangan Formation with a slope of $3 \%-8 \%$. Both of these landform units are in the same formation, the Pucangan Formation. The direction of groundwater flow follows the rock bed direction, namely from South to North and from Northwest to Southeast.

c) Irregular Flow Patterns

This pattern is found in the landform unit with the Kabuh Formation with a slope of 3\% - 
$8 \%$ and the Notopuro Formation with a slope of $0 \%-3 \%$. Each landform unit is located in two different rock formations, namely Kabuh Formation and Notopuro Formation. Kabuh Formation has a groundwater flow direction which flows in the direction of the slope of the rock bed from North to South, but there is also a direction from West to East. In Notopuro Formation, the direction of shallow groundwater flow from South to North is in the same direction as the slope of the rock bed. But in the western part of Krikilan Village, the groundwater flows irregularly, some from West to East and West to North.

2. Characteristics of Shallow Groundwater in the Sangiran Dome

Determination of shallow groundwater characteristics in the Sangiran Dome is measured by physical and chemical parameters used in this research are the degree of acidity $(\mathrm{pH})$, temperature and Electrical conductivity (DHL). a) Shallow Groundwater pH Data in the Sangiran Dome in 2019

The degree of acidity $(\mathrm{pH})$ is influenced by the minerals making up the host rock. The amount of rock mineral content in groundwater affects the $\mathrm{pH}$ value. 0-6 is acid, 7 is neutral, $8-14 \mathrm{i}$ alkalie. Based field survey result, the $\mathrm{pH}$ of shallow groundwater in the Sangiran Dome are divided into 3 classifications, namely:

1) Neutral

Wells that have groundwater with a neutral $\mathrm{pH}$ of 35 points are scattered in the Notopuro Formation and the Pucangan Formation. The two formations are composed of different rock arrangements. Notopuro Formation is composed of conglomerate rocks and tuff resulting from volcanic lava deposits formed in the terrestrial environment. Whereas the lower Pucangan Formation is composed of volcanic breccia rocks from the Mount Merapi Purba and Mount Lawu Purba volcanic 
deposits that change the

Sangiran Dome environment into swamps. The deposits contain quartz minerals and feldspar which have acidic properties. The deposition process that contains organic components can cause $\mathrm{pH}$ values to decrease.

2) Alkalie

Wells that have groundwater with base $\mathrm{pH}$ of 35 points are found in Kabuh Formation, Pucangan Formation and Kalibeng Formation. Kabuh Formation is composed of conglomerate rocks and tuffs which contain fossils of freshwater mollusks. The upper Pucangan Formation is composed of black clay, whereas that indicates the presence of seawater trangresi. Claystone minerals contain smectite mineral deposits which have alkaline properties. Whereas the Kalibeng Formation continues to be composed of claystone and limus limus. Formation in the formation there are many aragonite minerals and calcite minerals that contain the chemical element calcium carbonate $(\mathrm{CaCO} 3)$ found in mollusk fossils. The deposition of this mineral causes the constituent rocks to have basic properties.

3) Acid

Wells whose acidic $\mathrm{pH}$ is only found in well number 13 with a $\mathrm{pH}$ of 5.9 and located in the Notopuro Formation. The $\mathrm{pH}$ of well water in this formation is largely neutral. The rock composition of Notopuro Formation consists of conlomerate rocks and tuff resulting from ancient Merapi Mountain lava deposits and these deposits contain a lot of organic minerals that cause acidic $\mathrm{pH}$. 


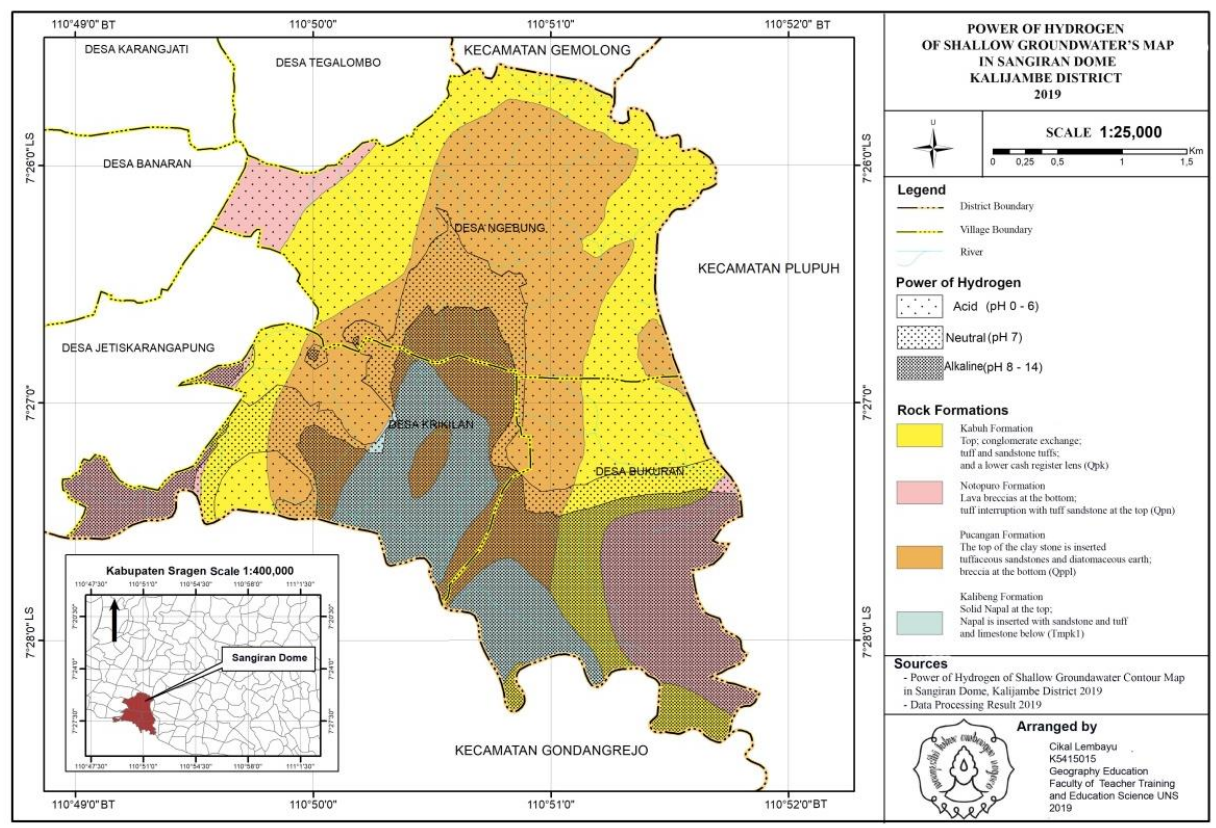

Figure 3: Map of Shallow Groundwater pH Classification in the Sangiran Dome in 2019

b) Shallow

\section{Groundwater}

Temperature Data in the

Sangiran Dome in 2019

Regulation of the Minister

of Health of the Republic of

Indonesia Number 32 Year 2017

concerning

Environmental

Health

Standard Quality Standards and Water Health

Requirements for Hygiene

Hygiene, Swimming Pools,

Solus Per Aqua, and Public

Baths states that the minimum and maximum temperature limits of ground water can be said to be good if it ranges from $20^{\circ} \mathrm{C}-30^{\circ} \mathrm{C}$ and the difference between the lowest groundwater temperature and the highest groundwater temperature during checking of no more than $3^{\circ} \mathrm{C}$.

Based on field survey result, known that the lowest temperature of shallow groundwater in the Sangiran Dome is $29.1^{\circ} \mathrm{C}$ and the highest is $31.8^{\circ} \mathrm{C}$. The highest temperature difference with the lowest temperature of $2.7^{\circ} \mathrm{C}$. The number of shallow groundwater samples successfully measured was 67 sample points classified as shallow groundwater in the Sangiran Dome in good condition, because the 
temperature value of each well is $20-30^{\circ} \mathrm{C}$ the difference between the lowest groundwater temperature and the highest groundwater temperature is not more than $3^{\circ} \mathrm{C}$.

The difference in groundwater temperature affects the mineralization process that occurs in the constituent rocks of the aquifer and affects the reaction of chemical elements. The higher groundwater temperature will further accelerate the process of dissolving the aquifer making minerals so that there will be less sediment. Classification of shallow groundwater temperatures in the Sangiran Dome in 2019 will be presented on figure 5 below.

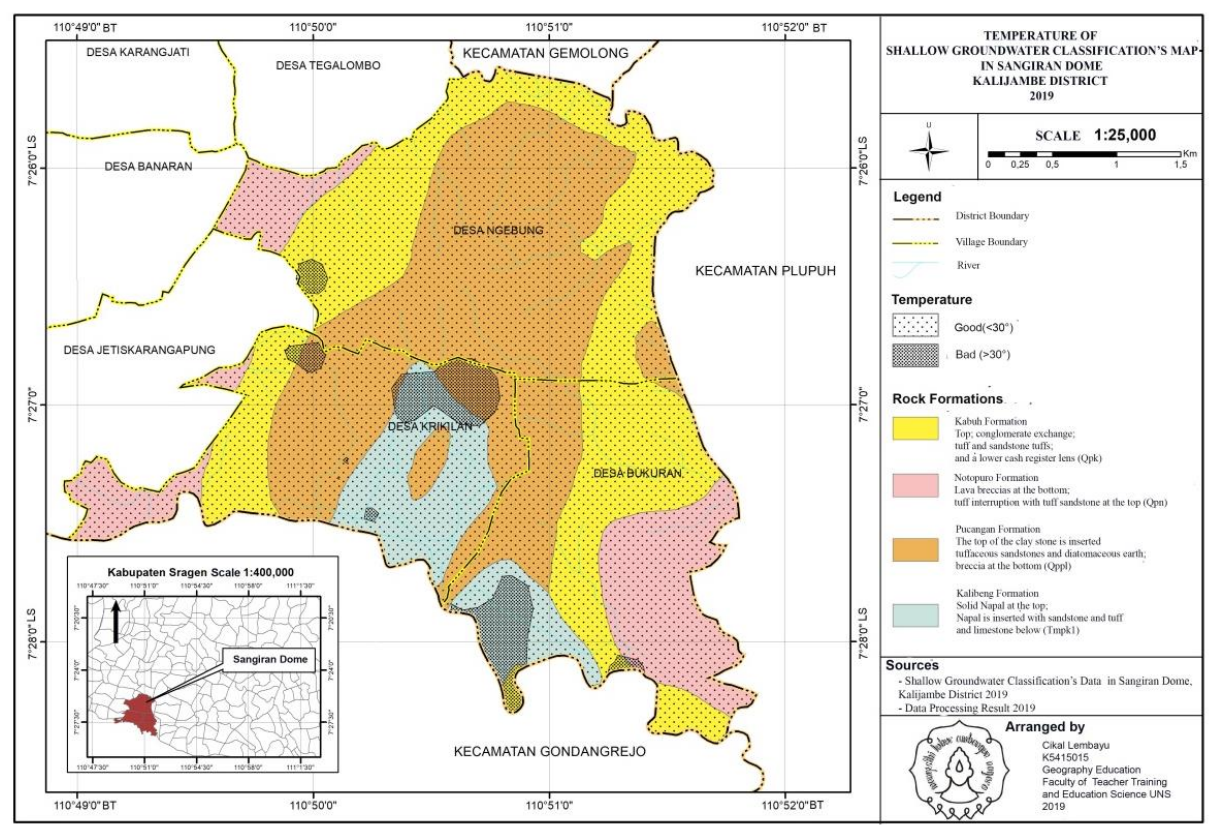

Figure 5: Map of Shallow Groundwater Temperature Classification at Sangiran Dome in 2019

c) Shallow Groundwater DHL Data in Sangiran Dome in 2019

\section{Electrical Conductivity} (DHL) is the ability of water to conduct electric current. Salinity of water is indicated by the presence of DHL, the more salty the groundwater the higher the salinity. The length of time the water comes in contact with rocks causes the amount of dissolved minerals to increase. DHL reductions 
are carried out on shallow groundwater well water samples usingEC meters. Based on Suharjo (2004) in Latifah (2014: 6), There are 3 classes of DHL, <1000 is low, $1000-2500$ is middle, and $>2500$ is high.

Based on field survey result, the DHL shallow groundwater classification in the Sangiran Dome is divided into 2 classifications, namely:

1) Low DHL

Wells that have low DHL are found in the Notopuro Formation, Kabuh Formation, and Pucangan Formation. Notopuro Formation and Kabuh Formation are the youngest formations so that water has contact with rocks in a shorter time, besides that because the shallow groundwater temperature in the Sangiran Dome is included in the good category, there are not many minerals involved in the groundwater. The genesis process that occurs in the
Notopuro Formation marks the formation of the terrestrial environment. Kabuh Formation was estimated as a very extensive river environment at the time, so it was not affected by the marine environment.

Groundwater in the Pucangan Formation has a higher DHL value compared to the groundwater DHL value in the Notopuro and Kabuh Formations. That is because the Pucangan Formation was formed earlier than the Kabuh Formation and Notopuro Formation, so groundwater contact with rocks lasted longer. The formation of the Pucangan Formation indicates the presence of sea water transgression.

2) DHL Intermediate

Wells that have medium DHL are scattered in the Kalibeng Formation. This formation is composed of napal rock and black clay and is 
indicated as a marine

environment. It is the

oldest formation, so that

ground water contact with

rocks takes a very long

time, causing the amount

of rock minerals dissolved

in groundwater. The

marine environment also

influences the higher value of DHL when compared to the three formations above.

Distribution of

shallow groundwater DHL conditions at the Sangiran Dome is displayed on figure 6 of the DHL Classification at the Sangiran Dome in 2019.

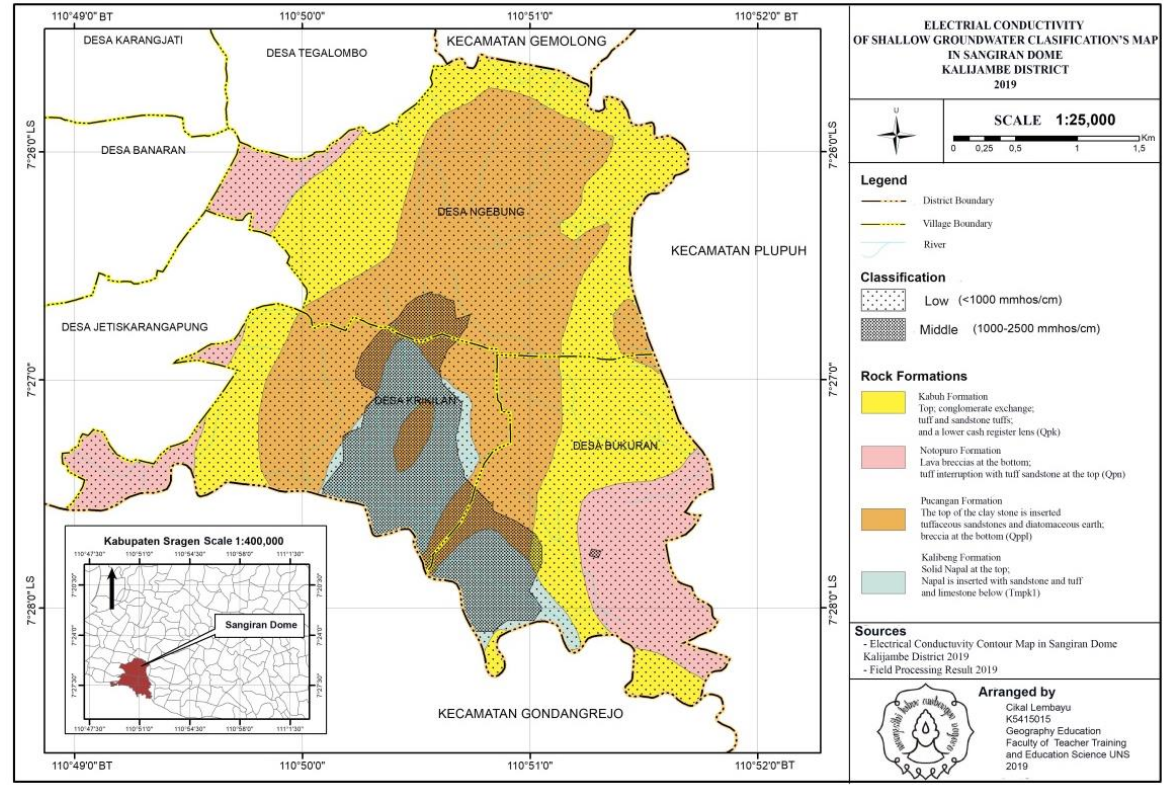

Figure 6: DHL Classification at the Sangiran Dome in 2019

\section{CONCLUSIONS}

Shallow groundwater flow patterns are concentrated, diffuse and irregular. The concentrated groundwater flow pattern is formed at the landform unit in the Kalibeng Formation. The direction of groundwater flow is centered in accordance with the direction and slope of the bedding, from West to East. This groundwater flow pattern is formed because it is influenced by the region in the form of a basin.

Groundwater flow pattern spreads there are landform units in the Pucangan Formation. The direction of groundwater flow follows the rock bed direction, namely from South to North and from Northwest to Southeast. The morphology of the ridge causes the groundwater pattern to spread. 
Irregular groundwater flow patterns are found in the landform units located in the Kabuh Formation and Notopuro Formation. The direction of groundwater flow is in the same direction as the bedrock, but some are not.

Neutral classification is found in the Notopuro Formation, the lower Pucangan Formation. Base $\mathrm{pH}$ classifications are found in the Kabuh Formation, the upper Pucagan Formation, and the Kalibeng Formation. Acidic $\mathrm{pH}$ classification is found in the Notopuro Formation.

Classification of shallow groundwater temperatures in the Sangiran Dome is included in the classification either because the difference in the temperature of the shallow groundwater is lowest with the highest groundwater temperature of less than $3^{\circ} \mathrm{C}$ or at $2.7^{\circ} \mathrm{C}$. Groundwater temperature is relatively good because sunlight can penetrate into aquifers and dissolving minerals can run quickly.

Low DHL classification is found in landform units which are in Notopuro Formation, Kabuh Formation, and Pucangan Formation. While the medium DHL value is in the landform units in the Kalibeng Formation. The size of the DHL value is influenced by the type of rock and the genesis process that affects the formation of rock formations.
Based on research that has been done, suggestions can be given to the community is thy can play an active role in order to maintain environmental groundwater resources. Sragen Regency Government can provide counseling regarding clean water requirements. Also this research needs to be further developed for more detailed locations for shallow groundwater distribution.

\section{E. REFERENCES}

Archwort, R.I. 2009. Surface water and groundwater: understanding the importance of their connections. Australian Journal of Earth Sciences, 56:1, 1-2. Australia: University of New South Wales.

Gharehchahi Saeideh. 2017. Volcanic Process and Landforms. USA: Texas State University.

Krussman, G.P. and Ridder, N.A. 1970. Analysis and Evaluation of Pumping Test Data. Wageningen: International Institute for Land Reclamation and Improvement.

Latifah, Dina. 2006. Analisis Daya Hantar Listrik (DHL) Airtanah Asin dan Dampak Pada Peralatan Rumah Tangga di Kecamatan Grogol. Skripsi. Surakarta: Universitas Muhammadiyah Surakarta.

Ojo, et al. 2012. Groundwater: Characteristics, qualities, pollutions and reatments: An overview. International Journal of Water Resources and Environmental Engineering Vol. 4 (6), pp. 162-170, June 2012. South Africa: Durban University of Technology.

Satyana, A.H. 2008. Sangiran Dome, Central Java : Mud Volcanoes 
Eruption, Demise of Homo erectus erectus and Migration of Later Hominid. Indonesian Association of Geologists 37th Annual Conference and Exhibition, Bandung 26-30 August 2008.

Tika, M P. 2005. Metode Penelitian Geografi. Jakarta: Bumi Aksara.

Todd, D.K. 1980. Groundwater Hydrology. Wiley: New York.

Van Zuidam, R.A. 1983. Guide to Geomorphologic-aeria photographic interpretation and mapping. Enschede: Section of Geology and Geomorphology, ITC.

Zeffitni. 2012. Agihan Spasial Ekologikal Potensi Airtanah untuk Kebutuhan Domestik di Cekungan Airtanah Palu Provinsi Sulawesi Tengah. Jurnal MANUSIA DAN LINGKLINGAN, Vol. 19, No. 2, Juli.2012, $\quad$ 105-117. Palu: Universitas Tadulako Palu. 